\title{
Att stå på egna ben - om övergången från samhällsvård till vuxenliv
}

\author{
INGRID HÖJER \& YVONNE SJÖBLOM
}

\begin{abstract}
Artikeln behandlar hur övergången från ung till vuxen ter sig för en sårbar grupp av unga, de som varit $i$ samhällsvård. Vilken roll spelar vården, socialtjänsten och den biologisk a familjen för dem? Vilken betydelse fär den förlängda ungdomstiden för ungdomar vars sociala nätverk är resurssvaga?
\end{abstract}

\section{Inledning}

Övergången från ung till vuxen är en omvälvande fas för de flesta ungdomar. Viktiga beslut skall fattas om utbildning, arbete, familjebildning och bostad. Utformningen av denna transitionsfas kan vara avgörande för ungdomens framtida livssituation. Internationell forskning visar att övergången från ung till vuxen oftare inträffar tidigare och görs på kortare tid för de ungdomar som varit placerade i familjehem eller hem för vård och boende (HVB-

Ingrid Höjer, docent, Institutionen för socialt arbete, Göteborgs universitet.

Yvonne Sjöblom, docent, Institutionen för socialt arbete, Stockholms universitet. hem), än för deras jämnåriga utan sådana erfarenheter (Stein 2006; Wade 1999). De ungdomar som har de mest begränsade förutsättningarna för att klara övergången från ung till vuxen kan därmed också sägas ha de snävaste ramarna för att ta sig igenom den (Bakketeig 2008).

Socialtjänstens dygnsvård är ett område i expansion med ett ökat antal ungdomar som placeras (Sallnäs 2000). Drygt 22700 barn och unga hade heldygnsinsats någon gång under 2008 (Socialstyrelsen 2009). Hur eftervården är organiserad, och hur ungdomar som går ut i ett självständigt liv efter en placering ska få sina behov tillgodosedda, har länge varit en förbisedd fråga. I motsats till länder som Storbritannien och Norge har inga strukturerade eftervårds- 
program byggts upp i Sverige. Först 2008 kompletterades socialtjänstlagen med en paragraf som närmare behandlar eftervården. Där står att socialtjänsten "ska tillgodose det särskilda behov av stöd och hjälp som kan finnas sedan vård och fostran utanför det egna hemmet upphört" (5 kap. $1 \S$ SoL). Vad denna lagförändring får för konsekvenser i praktiken saknas det hittills kunskap om.

Flera nationella registerstudier har genererat viktig kunskap om situationen för dem som tidigare varit placerade i socialtjänstens dygnsvård. Emellertid är kunskapen begränsad då det handlar om vad de unga själva finner ha varit betydelsefullt för övergången till ett självständigt liv efter vården. I denna artikel presenteras resultat från en kvalitativ studie där 16 ungdomar mellan 18 och 22 år har intervjuats vid två tillfällen. ${ }^{1}$ Syftet med artikeln är att belysa hur unga som lämnar socialtjänstens dygnsvård uppfattar övergången från vård till ett självständigt vuxenliv. För att förstå hur de unga förhåller sig till några avgörande livsområden under övergången från ung till vuxen är det väsentligt att analysera empirin utifrån ett individuellt perspektiv men också utifrån de ungas erfarenheter av familjeliv, nätverk och det omgivande samhället (Andersson 2008).

\section{Tidigare forskning}

Tidigare svensk forskning, baserad på

1 Forskningsprojektet har etikprövats av regionala etikprövningsnämnden i Göteborg 200511-25. registerstudier, har visat att ungas situation då de lämnar dygnsvården för att leva ett självständigt liv, ofta blir problematisk. Bland annat fann Vinnerljung et al. (2006) att ungdomar som hade varit placerade i dygnsvård sökte sjukhusvård för självmordsförsök i betydligt större utsträckning än andra ungdomar. Deras mentala hälsa var också sämre (ibid.). Forskningsresultat har visat att goda skolprestationer är ett starkt skydd för utsatta barn. Samtidigt har barn och ungdomar som växer upp i samhällets vård en 40-procentig överrisk för att bara ha grundskoleutbildning i vuxen ålder (Social rapport 2010). Således visar forskningen att den avsedda kompensatoriska effekten med en placering i dygnsvård i många fall uteblivit.

Brittisk forskning indikerar att de ungdomar som blir kvar i dygnsvård fram till de sena tonåren sällan har möjlighet att återförenas med sina ursprungsfamiljer (Biehal \& Wade 1996). Kontakten med föräldrarna kan ha blivit problemfylld och mindre frekvent under placeringens gång (Höjer 2001). Det kan medföra att stödet från föräldrarna till ungdomarna då placeringen avslutas är svagt. Många ungdomar som varit placerade i dygnsvård har också avlidna föräldrar. Vid 25 års ålder hade $36 \%$ från denna grupp förlorat en eller båda föräldrarna, jämfört med 7 \% från normalpopulationen (Franzén \& Vinnerljung 2006).

Parallellt med en komplicerad, eller obefintlig, relation till föräldrarna kan barn och ungdomar få problem att skapa hållbara och stabila relationer till fosterföräldrar då placeringen i familjehemmet avslutats (Andersson 2005). För ungefär $50 \%$ av de ungdomar som var 13 år eller äldre då de 
placerades avbröts placeringen oplanerat (Vinnerljung et al. 2001). En sådan oplanerad avslutning av en familjehemsplacering kan medföra att kontakten med fosterföräldrarna också avbryts, vilket betyder att den unge inte heller erhåller något stöd från sina fosterföräldrar i övergångsfasen till ett självständigt liv (Biehal \& Wade 1996).

Stödet från socialtjänsten kan också vara bristfälligt. Under den tid då barn och ungdomar är placerade i dygnsvård är stödet och kontrollen inbyggd i organiseringen av det sociala arbetet, men då placeringen avslutas kan stödet och engagemanget i placerade ungdomar helt upphöra. Flera forskare finner att socialtjänsten ofta brister då det gäller att stödja och följa upp ungdomar som lämnar vård i familjehem eller på institution (Garnett 1992; Stenström 1998; West 1995; Wade 1999).

\section{Övergången från ungdomstid till vuxenlivi välfärdssamhället}

I det moderna samhället har ungdomstiden blivit längre i den meningen att unga människor under en mer utsträckt period befinner sig i processen att gå från ung till vuxen. Denna förlängning har uppstått till följd av ökade utbildningskrav, en osäker arbetsmarknad men också förändrade värderingar och normer. Den ålder då unga har etablerat sig på arbetsmarknaden är i genomsnitt 28 år (Ungdomstyrelsen 2005).

En konsekvens av denna förskjutning är att unga blir beroende av sina föräldrar under en längre tid (Mørch 1996; SOU 2001:55; Sjöblom 2002). Även om unga från de nord- iska länderna i ett internationellt perspektiv flyttar hemifrån relativt tidigt (Vogel 2003), visar både svensk och norsk forskning (Espvall \& Dellgran 2006; Hellevik 2005) att föräldrars ekonomiska, praktiska och sociala stöd till utflyttade barn var betydande. För den grupp av unga som lämnar dygnsvården kan det innebära att de hamnar i en alltmer ofördelaktig situation jämfört med jämnåriga som har tillgång till både socialt och ekonomiskt stöd från föräldrar. Många unga människor som lämnar vården måste ensamma ta ansvar för att forma sina liv mycket tidigare och på betydligt kortare tid än vad andra ungdomar behöver göra (Biehal et al. 1995; Jones 1995; Little et al. 1995; Biehal \& Wade 1996; Courtney \& Wong 1996; Havik \& Backe-Hansen 1998; Broad 1999; Stein 2002, 2008). Detta faktum belyses också $i$ den norska kartläggningen av eftervård för den här gruppen (Bakketeig 2008).

Övergångsfasen från ungdomstid till vuxenliv präglas av en ökad variation, individualisering och fragmentarisering (Walther 2006). Övergången till vuxenlivet kan också karaktäriseras av att den kan gå "fram och tillbaka" och växla mellan perioder av "ungdomslikt" beroende och perioder av självständighet och vuxenliv. En effekt av ett sådant "fram-och-tillbaka-förhållande" kan vara att unga finner det allt svårare att bestämma sig för om de är vuxna eller om de fortfarande är ungdomar. Ofta väljer de att definiera sig som någon som är "mittemellan" till exempel kan de tycka sig höra till kategorin "unga vuxna". Walther (2006) benämner denna växling av beroende- och självständighetsperioder som "jojo-övergångar". En intressant frågeställning i rela- 
tion till begreppet förlängd ungdomstid är hur den svenska välfärdsmodellen påverkar de ungas position under övergången från ung till vuxen.

Enligt Esping-Andersens (1990,1999) välkända kategorisering av välfärdsregimer i Europa, hör Sverige, tillsammans med de andra Nordiska länderna, till den socialdemokratiska välfärdsmodellen. Denna modell kännetecknas av allmänna förmåner, en jämlik fördelning av de sociala resurserna, en socialförsäkringsmodell som baseras på medborgarskap och en generös familjepolitik. Förmånerna är sammankopplade med tillhörighet till arbetsmarknaden och kvalificeringsvillkor som kräver en viss period av lönearbetet. Barn och unga är grupper som inte självklart har tillträde till arbetsmarknaden och därför inte kan åtnjuta dessa bidrag från välfärdsstaten för egen del utan endast genom att tillhöra en familj. Det innebär att unga i och med svårigheten att etablera sig på arbetsmarknaden också blir osynliga som egna subjekt och aktörer i den svenska välfärdsmodellen. Det är ett faktum som inte har uppmärksammats. Vi vet heller inte vilka konsekvenser detta får för sårbara grupper av unga, som de som varit i samhällsvård (Eydal \& Satka 2006).

\section{Resilience}

Begreppet resilience och dess teoretiska utgångspunkter kan skapa förutsättningar att förstå varför och hur ungdomar som växt upp under svåra förhållanden, som de som varit placerade i samhällsvård, klarar övergången från dygnsvård till ett självstän- digt vuxenliv (Masten et al. 2004; Stein 2005; Andersson 2008). Avgörande för en individs livsutveckling kan vara förekomsten av skyddande faktorer. Kännetecknande för skyddsfaktorer är att de kan medverka till en gynnsammare utveckling just vid förekomsten av risker i en individs liv. Skyddsfaktorn interagerar således tillsammans med riskfaktorn - om det inte finns någon risk blir inte skyddsfaktorn heller betydelsefull (Stattin \& Magnusson 1996). Skyddande faktorer benämns också som resilience. Detta begrepp kan mycket kortfattat beskrivas som förmågan hos vissa individer att klara sig i livet trots svaga förutsättningar och svåra livsförhållanden. Rutter (1999) definierar resilience som en relativ förmåga att klara av svåra psykosociala erfarenheter. Lagerberg och Sundelin (2000) menar att begreppet även kan översättas med det svenska ordet motståndskraft - de menar att resilience kan betecknas som förmågan att "komma igen" - att klara av sitt liv trots dåliga odds. Forskning visar att inre och yttre anpassning så som tillgång till en positiv självbild eller till ett fungerande socialt nätverk är betydelsefulla faktorer för att öka förmågan till motståndskraft (Masten et al. 2004; Moen 1997). Att klara av skolan på ett bra sätt är exempel på en viktig skyddsfaktor hos unga (Werner \& Smith 1982). Rutter et al. (1998) fann att motståndskraft hos unga med erfarenhet av separationer och svåra familjeförhållanden var kopplad till en förtroendefull och varm relation med åtminstone någon familjemedlem eller annan signifikant vuxen, en känsla av att ha kontroll över sitt liv, och att genom "vändpunkter" i livet hitta möjligheter att förändra en tidigare 
negativ utveckling. Vändpunkter inträffar ofta under övergången från ung till vuxen. Då kan det skapas möjligheter till "en andra chans" för den unge så som till exempel att ingå i en relation med en stabil partner, hitta arbete och utbilda sig samt genom tillgång till vuxenstöd. Individens adaptiva förmåga (den inre anpassningen) i interaktion med de möjligheter som finns i omgivningen (den yttre anpassningen) skapar möjligheter för vändpunkter och livsval som kan ge ett positivt livslopp (Andersson 2008; Mastern et al. 2004).

\section{Metod, material och analys}

I studien "Från vård till vuxenliv" och i uppföljningsstudien "Vad hände sedan"2 intervjuades 16 ungdomar mellan 18 och 22 år vid två tillfällen med ca 1,5-2 års mellanrum. Syftet med att återkomma till ungdomarna med en uppföljande intervju var att kunna följa deras väg från ung till vuxen, från att de var placerade, till att de faktiskt hade lämnat samhällsvården och påbörjat en etableringsprocess mot vuxenblivandet. Genom att ta del av deras erfarenheter och höra deras uppfattningar ville vi förstå hur den här övergångsfasen tedde sig över tid för dem. Tio av ungdomarna var placerade på grund av deras föräldrars alkoholmissbruk och/eller psykiska sjukdom. Tre ungdomar var placerade på grund av eget beteende och tre på grund av allvarliga konflik-

2 "Från vård till vuxenliv" genomfördes år 2006 och "Vad hände sedan" genomfördes år 2008. Vi vill tacka Stiftelsen Allmänna Barnhuset, som har finansierat studien. ter i familjen. Tio av ungdomarna var födda i Sverige av svenska föräldrar, två hade föräldrar födda i Norden, och fyra var födda $i$, och hade föräldrar från, ett utomeuropeiskt land. Vid den första intervjun hade åtta ungdomar lämnat, eller stod i begrepp att lämna vård $\mathrm{i}$ familjehem, och åtta hade lämnat vård i HVB-hem. Sex flickor och tio pojkar intervjuades. Metoden som användes var halvstrukturerade intervjuer. Frågorna utgick från en frågeguide med olika frågeområden inriktade på ungdomarnas egna upplevelser av att ha varit i dygnsvård, samt det stöd de erhållit då de lämnade vården.

För att få en uppfattning om vilket stöd som erbjöds i ungdomarnas professionella och privata nätverk, genomfördes också strukturerade telefonintervjuer med åtta fosterföräldrar, åtta behandlingsassistenter på HVB-hem, 15 socialsekreterare och fem familjehemssekreterare.

Vid den uppföljande studien intervjuades ungdomarna 1,5-2 år efter den första intervjun. Två ungdomar avböjde då att delta, varför endast 14 ungdomar intervjuades vid det tillfället. I denna artikel redovisas främst resultat från intervjuerna med ungdomarna.

\section{Urval}

Kontakt med ungdomarna etablerades genom familjehemsverksamheterna i Göteborg, genom socialsekreterare inom individ- och familjeomsorgen i Stockholm och direkt med familjehemssekreterarna. Socialsekreterarna, familjehemssekreterna och personal på HVB-hem tillfrågade alla ungdomar som de visste hade lämnat 
familjehem/ HVB-hem eller var på väg att göra så, om de kunde tänka sig att bli intervjuade. Om de gav sitt samtycke, kontaktade vi dem på telefon. Ett par av de tillfrågade ungdomarna avböjde deltagande. Då vi fått kontakt med 16 ungdomar ansåg vi att vi hade ett tillräckligt stort urval för att uppnå syftet med studien. Många av ungdomarna hade varit placerade i dygnsvården under lång tid. Tio ungdomar hade erfarenhet av tre eller flera placeringar. En av ungdomarna hade varit placerad vid 17 tillfällen och en annan vid 19 tillfällen. Medelvärdet för placeringstiden för dem som varit placerade i familjehem var 11,5 år, jämfört med 6,3 år för dem som varit placerade på HVB-hem.

Vårt urval av ungdomar är beroende av familjehemssekreterares, socialsekreterares och HVB-personals goda vilja, och deras kunskap om ungdomarna. Ett sådant urval kan medföra en risk för att det är de mest positiva eller de mest "lyckade" ungdomarna som väljs ut, och att inte ungdomar med mera problematiska förutsättningar tillfrågas. Emellertid visar intervjuerna att en stor majoritet av ungdomarna hade svåra erfarenheter bakom sig och att deras övergång från vård till vuxenliv inte alltid varit enkel. De ungdomar vi intervjuat har också haft mycket skiftande upplevelser. Vårt urval kan därför sägas ge en god bild av den stora variationen inom den här gruppen.

\section{Bearbetning och analys av intervjuerna}

Alla ungdomsintervjuer transkriberades. De kodades och bearbetades i ett kvalita- tivt dataprogram (NVIVO 8). Datamaterialet bearbetades och omstrukturerades i övergripande kategorier. Dessa kategorier har arbetats fram i en induktiv process där de teoretiska utgångspunkterna tjänade till att fördjupa och tydliggöra analysen av empirin. Kategorierna som slutligen kom att strukturera resultatredovisningen var ekonomiskt stöd, boende, arbete/utbildning, framtidsplaner, kontakt med föräldrar och övrigt socialt nätverk, stöd från fosterföräldrar/HVB-hem och stöd från socialtjänsten. Den första intervjuomgången har jämförts med den andra intervjuomgången och $i$ analysen av materialet har skillnader och likheter i de ungas utsagor mellan den första och andra intervjun lyfts fram.

\section{Resultat}

\section{Ekonomiskt stöd}

Resultatet från intervjuerna visade att ungdomarna oroade sig och kände sig osäkra för sin ekonomi och planeringen av densamma. Samtliga ungdomar gav i intervjuerna uttryck för ett tydligt uttalat behov av stöd i dessa frågor. Oron för ekonomin kan förstås mot bakgrund av att de saknade den familj eller annan närstående som unga i allmänhet har som kan bidra ekonomiskt och utgöra en buffert. De unga som ingick $\mathrm{i}$ vår studie hade efter placeringens slut själva ansvar för sin ekonomiska försörjning. Stödet som efterfrågades handlade mindre om bidrag till försörjning och mer om att få kunskap i hur man planerar sin ekonomi. De oroade sig för att de inte skulle komma ihåg att betala sina räkningar 
och för att pengarna inte skulle räcka till för alla utgifter. För att klara av övergången till vuxenlivet var det väsentligt för dem att kunna lägga upp en budget och att göra en långsiktig planering. Vid den första intervjun var detta ett återkommande tema. Även vid den andra intervjun uttryckte en majoritet av ungdomarna en oro över ekonomin, men också över ett fortsatt behov av råd och stöd för att få ekonomin att fungera. Nedanstående citat från intervjupersonen Anders beskriver hur han upplevde att hans återkommande diskussioner med fosterföräldrarna gav honom en kompetens att själv kunna hantera sin ekonomi.

Det har vart mitt största problem med ekonomin ... man har pengar och 'men jag ska bara köpa det och bara det, det kostar ju inget.' Så helt plötsligt så har man gjort av med fyra, fem tusen på en månad. På en massa onödigt bara då. Men så det ... men dom har ändrat mig mycket genom åren. Att tänka mycket mognare, att tänka framåt istället för bara nu. Att planera ... framtiden då månadsvis istället för veckovis till exempel. (Anders, 22 år, intervju 2).

\section{Boende}

Boendet är viktigt, eftersom det utgör en viktig grundförutsättning för att kunna försörja sig och skapa sitt självständiga liv. Utan boende går det varken att studera eller arbeta. Vid den första intervjun bodde de flesta ungdomarna som varit placerade i egen lägenhet som de ordnat på egen hand eller med hjälp av fosterföräldrarna. Ingen av dem hade fått hjälp av socialtjänsten.
Av dem som varit placerade på HVB-hem bodde flera i tränings- eller utslussningslägenhet. Det är en viktig del i att lära sig att klara sig själv och att lära sig att planera och klara alla praktiska bestyr, och träningslägenheten är en form av stöd som ungdomarna var väldigt nöjda med. Kombinationen av självständighet och stöd uppfattades som positiv och tryggt av ungdomarna. Så här sade Karim:

Om det går bra på HVB-hemmet så finns det stora möjligheter att få flytta till egen lägenhet till ett mellanboende där man har mycket mer frihet och där kan man ocksà få hjälp och sedan kan du flytta till träningslägenhet. Det blir lättare och lättare för varje gång. Jag trodde från början att det var lätt att bo själv. Men det är mycket jobbigt att tvätta kläder och det här med städning. Men det har gått över nu. Jag har inte så mycket kunskap om Sverige och hur det fungerar. Så det är bättre att ställa frågor så det är bra att jag har personalen på mellanboendet för dom vet mycket. Dom är svenskar, så dom vet. (Karim, 19 år, intervju $1)$.

Vid den andra intervjun bodde samtliga 14 utom en i eget boende, sex tillsammans med pojk- eller flickvän och åtta på egen hand.

\section{Arbete och utbildning}

Vid den första intervjun studerade åtta ungdomar antingen på gymnasiet, vuxengymnasiet eller på grundskolenivå. En gjorde militärtjänst, tre var arbetslösa och 
fyra hade osäkra arbeten, som till exempel telefonförsäljare.

En aspekt som framträder tydligt i det insamlade intervjumaterialet är den betydelse som ungdomarna tillskriver sina skolerfarenheter. Flera hade tidigare misslyckats i skolan. De hade skolkat eller blivit utestängda från skolan, inte klarat skolarbetet och varit placerade i särskola. Erfarenheter av misslyckanden i skolan hade format ungdomarnas självbild på ett negativt sätt. Påfallande många beskrev dock hur de hade kunnat vända en negativ skolerfarenhet till något positivt under de sista åren de varit placerade i dygnsvården. För fyra av de ungdomar som varit placerade $i$ familjehem innebar bytet av fosterfamilj i 15-16-årsåldern, efter sammanbrott av tidigare placeringar, att deras skolprestationer förbättrades. De nya fosterföräldrarna ansåg att skolan var viktig och de uppmuntrade, stöttade och ställde krav på närvaro. Fosterföräldrarna hjälpte ungdomarna att uppfatta sig själva som kompetenta och dugliga. Med hjälp av engagemang och stöd från personal, i kombination med god kvalitet på den utbildning som erbjöds, hade även flera av de unga som varit placerade $i$ HVB-hem haft möjlighet att förbättra sina skolresultat. Denna process från misslyckad elev till studiemotiverad och kompetent elev, beskrevs av ungdomarna som en viktig vändpunkt i livet, som påverkade deras självbild och identitet. Vid den andra intervjun hade 12 ungdomar avgångsbetyg från gymnasiet.

Vid den andra intervjun arbetade de flesta ungdomarna. Två studerade fortfarande på gymnasiet, en var arbetslös och ytterligare en sjukskriven. För de ungdo- mar som hade arbete handlade det oftast om korta och osäkra anställningar. En hade just avslutat en yrkesutbildning och planerade att resa en tid innan han gick vidare till högre utbildning. Ingen av ungdomarna hade vid det andra intervjutillfället startat någon form av eftergymnasial utbildning men flera hade sådana planer. Det som hindrade dem från att satsa på vidare utbildning var i några fall en osäkerhet om deras betyg var tillräckliga, men framförallt grundade sig deras tvekan i en rädsla för att sätta sig i ekonomisk skuld. Att ta ett studielån framstod för många som ett högriskprojekt, som de uttryckte en stor tveksamhet inför.

\section{Familjebildning}

Flera av de intervjuade ungdomarna talade om att bilda familj, men såg fortfarande barn som något som låg några år framåt $i$ tiden. De ville först etablera sig på arbetsmarknaden, hitta ett boende och ha ett stabilt förhållande innan familjebildandet. Vid den andra intervjun hade två redan fått barn och var mycket nöjda med att ha blivit föräldrar. Så här säger Martin vid den andra intervjun om hur han ser på sin framtid:

Jag bara försöker tänka framåt - på ljusa tider. Har uppnått mina mål - åtminstone till hälften. Det som är kvar är: villa, hund, ja... körkort också, eget företag, åka utomlands lite mer och så lite mer barn då... Det är väl det...(Martin 22 år, intervju 2).

De två som hade fått barn såg föräldraskapet som något positivt, som en viktig vänd- 
punkt i sina liv. Att få barn medförde att de hade fått en förankring i en familj, att ta ansvar för ett barn medförde en känsla av tillhörighet och kompetens.

\section{Kontakt medföräldrar}

Ungdomarnas upplevelse av stöd från föräldrarna under övergången från en placering i dygnsvård till självständigt vuxenliv, kan sägas vara beroende av den kontakt de tidigare hade haft med föräldrarna under placeringstiden. I många fall hade denna kontakt varit bristfällig eller rent av obefintlig. Då placeringen avslutades hade ungdomarna följaktligen oftast ingen kontakt att bygga vidare på. I de fall där det fanns en föräldrakontakt skedde denna oftast på ungdomarnas eget initiativ, inte på föräldrarnas, fosterföräldrarnas eller socialarbetarnas initiativ. Två mödrar var döda och både fäder och mödrar var i många fall så skadade av missbruk och/eller psykisk sjukdom att det var svårt, om inte omöjligt, att upprätthålla någon form av kontakt. Vid den första intervjun hade endast ett fåtal ungdomar fått någon form av stöd från föräldrarna då de flyttade från familjehemmet eller HVB-hemmet.

Vid den andra intervjun hade flera lyckats återuppta kontakten med föräldrarna, även i de fall där kontakten tidigare varit sporadisk eller obefintlig. Den återupptagna kontakten uppfattades som positiv, men den innebar egentligen inte att stödet från föräldrarna ökat. Tvärtom var det i många fall så att det var ungdomarna som upplevde att det var de som stöttade och tog ansvar för sina föräldrar.

\section{Stöd från fosterföräldrar/ HVB-hem}

För många av ungdomarna hade de vuxna som de lärt känna under placeringstiden kommit att bli viktiga stödpersoner även efter att placeringen avslutats. Det gällde framförallt de ungdomar som hade varit placerade i familjehem. Vad som avses med "stöd" är i huvudsak praktisk hjälp så som flyttning och inköp, så väl som rådgivning i både praktiska, ekonomiska och känslomässiga frågor.

I några fall uttryckte ungdomarna att de hade samma position i sina familjehem som fosterföräldrarnas biologiska barn och att de såg sina fosterföräldrar som självklara stödpersoner även efter vårdens upphörande. Även de ungdomar som hade varit placerade i familjehemmet under kortare tid kunde ha en stabil relation till sina fosterföräldrar och såg dem som viktiga stödpersoner även efter placeringen. För ungdomarna som varit placerade på HVB-hem hade de kontaktpersoner som de lärt känna under vårdtiden också fått en viktig roll i deras liv. I några fall var kontaktpersonen den enda vuxna som ungdomarna uppgav att de kunde vända sig till om de behövde känslomässigt stöd.

Vid den andra intervjun kvarstod de ungas upplevelse av stöd från familjehemmet och från kontaktpersonerna från HVBhemmet. Tre av ungdomarna såg familjehemmet som sin egen familj, ytterligare tre unga uttryckte att de hade god kontakt och fick stöd av fosterföräldrarna vid behov. En hade god kontakt med fosterfadern men en mycket dålig relation med fostermamman och ville därför inte ha någon fortsatt kon- 
takt med familjehemmet. Fem av de unga hade fortfarande kvar kontakten med sina stödpersoner från HVB-hemmen. Denna kontakt byggde helt på frivillighet från kontaktmännens sida men upplevdes av ungdomarna som mycket betydelsefull. För två av ungdomarna hade stödet från HVB-hemmet helt upphört.

Några av de ungdomar som bott i familjehem uttryckte en osäkerhet över huruvida de självklart skulle fortsätta att vara en del av familjehemmet och få tillgång till stöd från detta. Osäkerheten hade troligtvis sin grund i varierande faktorer, men den obeständighet som är kopplad till en familjehemsplacering (Vinnerljung 1996) kan vara en möjlig anledning. Fosterföräldrar skall ge god vård och fostran (6 kap §7 SoL) under tiden barnet eller den unge är placerad, men de skall inte ersätta föräldrarna, endast komplettera dem. Emellertid är föräldrarnas situation i många fall så komplicerad att kontakten mellan placerade barn och ungdomar och deras föräldrar är begränsad eller obefintlig. Här uppstår en motsägelsefull situation. Hedda placerades i familjehem vid fyra års ålder, men bytte familjehem då hon var 15, vilket för Hedda inneburit en mycket positiv förändring $i$ hennes liv. Hennes uttalanden nedan får illustrera upplevelsen av motsägelsefullhet som kan känneteckna en familjehemsplacering:

Min pappa då har nog med sitt eget och är absolut inte rätt person att hjälpa. Så man står ganska hjälplös ändå. Man vet inte riktigt... man sätter sig $i$ en konstig situation. När man har sitt avslutningsmöte så säger dom kanske att 'ja nu är inte det dina föräld- rar längre'. -'Nähä!' '.. Liksom jag har ändå bott där i fem år och så har dom sagt till att 'dom här ska vara dina föräldrar' och helt plötsligt efter fem år när jag är redo att klara mig själv: 'ja men det är inte dina föräldrar längre.' Föräldrar är väl föräldrar även ifall man bor där eller inte? (Hedda, 20 år, intervju 1).

Det förefaller som om det fanns en outtalad förväntan från socialtjänsten att fosterföräldrarna ska ge fortsatt stöd och inta en föräldraroll även efter placeringens slut, utan ersättning eller handledning från socialtjänsten. I våra studier gav också de flesta fosterföräldrar sådant stöd till ungdomarna men denna motsägelsefulla situation och outtalade förväntan var sällan problematiserad i de intervjuer som gjordes med familjehemssekreterare och socialsekreterare. Motsvarande situation kunde också gälla för personal på HVB-hem, där ungdomarnas kontaktmän tog på sig ett ansvar som ofta gick utöver det formella och stöttade ungdomarna helt på frivillig basis efter det att placeringen avslutats.

\section{Stödfrån socialtjänsten}

Vid den första intervjun uppfattade endast två av de ungdomar som lämnade vård $i$ familjehem att de fått någon form av stöd från socialtjänsten då vården avslutades. De övriga sex ungdomarna ansåg att de inte erhållit något sådant stöd. Flera menade att det var ett rent administrativt beslut, att "ärendet avlutats". För några hade det varit svårt att få förståelse för att de behövde någon mera hjälp eller få möjlighet att 
stanna längre i familjehemmet. De ungdomar som varit placerade i HVB-hem fick alla någon form av stöd i utslussningfasen. Det var tydligt att det för dessa ungdomar fanns tillgång till systematiskt stöd i större utsträckning än för de ungdomar som varit placerade i familjehem.

Vid den andra intervjun var det två som tidigare var placerade i HVB-hem som fortfarande hade kvar någon form av formellt stöd från socialtjänsten. Några hade dock kvar en informell kontakt med socialsekreterare eller familjehemssekreterare. Den kontakten uppskattades och betraktades som att en vuxen vän kontaktade dem.

Kontakten med socialtjänsten kunde upplevas på olika sätt. Anders citat nedan handlar om hur han upplevde sin kontakt med socialsekreteraren:

När jag slutade studenten, då hade ju inte socialen med mig att göra längre. Så att dom försvann ju direkt efter. /.../ när det gällde socialen då var det bara papper jag fick egentligen. Och så stod det vad dom ville eller nåt sånt där. Det var ju liksom aldrig nån som ringde mig eller nåt sånt där. (Anders, 22 år, intervju 2).

När Anders pratar om "socialen", syftar han på alla de socialsekretare som haft det formella ansvaret för placeringen, men som han egentligen aldrig lärt känna. Familjehemssekreteraren däremot har funnits kvar under alla de åtta år som Anders varit placerad. Flera av de ungdomar som vi har intervjuat har givit oss en liknande bild. Det är relationen till de professionella och kontinuiteten i relationen som är väsentlig och som medför att kontakten med soci- altjänsten uppfattas som meningsfull och stödjande. Följande citat från den andra intervjun med Anders illustrerar hur han upplevde detta förhållande:

En gaing ringde en socialsekreterare. Jag var ... jag hade hamnat i ett bråk när jag var ... vad kan jag ha vart? 16 år. ... (skratt) Och då ringde en socialsekreterare och skällde ut mig och sa att jag fär inte slåss. Och jag bara 'ja det var ju kul att höra'. Och jag minns ju, jag bara 'vem är du? och varför ringer du mig?' Hade det vart Anna (familjehemssekreteraren), då hade jag liksom verkligen bett om förlàtelse och skämts. /.../ Men ringer det nån människa jag aldrig hört förut, då bryr man ju sig inte speciellt mycket.... nej då är det Anna då. Men jag såg inte henne som 'socialen' eller vad man ska säga. Jag såg henne som en bra vän som ... har hjälpt mig genom livet bara. För alltså, man kan tänka det som att 'sociala' är såna människor jag inte tycker om. Kan man väl säga. Om man tänker genom mitt liv hur socialen har ... gjort och ... dom har gjort mycket fel. Dom har gjort mycket rätt också men, men man ser bara mest det här dom gör fel tycker jag. Såjag vet inte, det är därför jag inte sett Anna som 'social' utan mer som en vän då för att jag tycker hon, hon har bara gjort rätt. När hon väl gjorde fel, när socialen gjorde fel ... så kom Anna och bad om ursäkt. Och hon kan ... bara det att jag fyller år, då får jag en present av henne och såna här grejer ... nej, hon var underbar tycker jag. Hon var bra (Anders, 22 år, intervju 2). 


\section{Diskussion}

Vi har i denna artikel presenterat resultat från en studie där situationen för ungdomar som varit dygnsplacerade och deras övergångsfas från ung till vuxen studerats. Vår avsikt har varit att fånga in ungdomarnas subjektiva uppfattningar. Det innebär att ungdomarna själva ges tolkningsföreträde gällande sin situation. Genom att använda resilience som ett teoretiskt perspektiv i analysen och diskussionen av de ungas utsagor har vi kunnat finna några faktorer som både befrämjar och försvårar övergången från ung till vuxen efter avslutad samhällsvård.

För ungdomar på väg mot vuxenblivandet handlar det om att återknyta till tidigare signifikanta vuxna samt att bygga upp nya nära relationer, få tillgång till informellt och formellt stöd, skapa nätverk, få möjligheter till boende, få tillgång till arbete, utbildning och en trygg försörjning. De behöver också få möjlighet att under denna förlängda livsfas få pröva sig fram och få tillåta sig att "misslyckas" och våga prova sig fram igen.

För dygnsplacerade ungdomar råder speciella förhållanden som påverkar övergången från ung till vuxen. Vuxenlivet kan börja utan stöd från ursprungsfamiljen, familjehem eller HVB-hem. Hur deras vuxenblivande kommer att gestalta sig är precis som för andra kopplat till uppväxtförhållanden, skolerfarenheter, utbildningskompetens och familjerelationer, men det är dessutom starkt beroende av administrativa beslut och de kategoriseringar som görs inom socialtjänstens byråkratiska och administrativa ramar. För unga som lämnar dygnsvården kan det innebära att de hamnar i en ofördelaktig situation jämfört med jämnåriga som har tillgång till både socialt och ekonomiskt stöd från föräldrar.

Resultaten från de båda intervjustudierna visar entydigt att ungdomarna uttrycker oro för hur de ska hantera områden som ekonomi, arbete och möjlighet att ordna bostad efter dygnsvårdens upphörande. De uttrycker också en oro över att bli isolerade och utan emotionellt och praktiskt stöd efter att de har lämnat dygnsvården. Vid en jämförelse mellan intervju ett och två ser vi också att stödet från socialtjänsten hade minskat. De ungdomar som bäst klarat av transitionsfasen från vård till vuxenliv är de som har en god och stabil relation till vuxna signifikanta personer. Det kan vara fosterföräldrar, kontaktpersoner, pojk- eller flickväns familj, eller i något fall en biologisk förälder.

Flera av våra informanter har beskrivit en situation där de hela tiden fătt träffa nya socialsekreterare, vilket visar att socialtjänsten inte lyckats med att skapa kontinuitet i relationen mellan socialsekreterare och ungdomar. Ungdomarnas utsagor visar att kontinuerliga och förtroendefulla relationer till socialtjänstens personal är betydelsefulla.

Vid flera tillfällen framgår det tydligt att tillgång till ett fungerande socialt nätverk har en stor betydelse för de unga. Att det finns tillgång till stöd i kritiska situationer och att det finns möjlighet att pröva idéer och framtidsplaner med någon som de unga har förtroende för är viktigt. I detta sammanhang finns det anledning att reflektera över uppdraget som fosterförälder. Vad ingår i uppdraget? Upphör uppdraget som 
kompletterande förälder $\mathrm{i}$ samband med att placeringen avslutas, eller skall uppdraget förlängas? Även om många fosterföräldrar håller kvar kontakten med tidigare placerade ungdomar, är inte detta självklart, utan beror på de relationer som utvecklats mellan familjehemmet och den unge. Den otydlighet som finns kring vad som skall gälla efter det att en placering avslutas är problematisk, och behöver diskuteras.

\section{Att lyckas i skolan en viktig vändpunkt}

I resilienceforskningen (Rutter et al. 1998; Masten et al. 2004) framkommer att vändpunkter kan vara avgörande för att ändra livsbanor för barn och unga som lever i utsatta situationer. För de ungdomar vi intervjuat innebar en förändring från negativa till positiva resultat i skolan en sådan viktig vändpunkt. Men trots att de unga beskrev vikten av att lyckas i skolan, och hur det påverkade deras självbild, pekar också resultaten på hinder för dem att ta sig vidare i utbildningssystemen. Ingen av de unga hade vid den andra intervjun läst vidare vid universitet eller högskola, även om flera av dem hade planer på det. Trots att ungdomarna hade formell behörighet att söka högre utbildning efter gymnasiet var deras tvekan stor att ta det steget. Vad som hindrade dem var en kombination av osäkerhet om den egna förmågan och en framträdande osäkerhet inför den ekonomiska satsning det innebär att läsa vidare.

\section{Familjebildningoch kontakt med biologiska föräldrar}

Vid den andra intervjun hade flera ungdomar återupptagit kontakten med sina biologiska föräldrar, och en tidigare bruten kontakt hade kunnat återupprättas. Detta uppfattades som positivt av ungdomarna. Det gav dem en känsla av kontinuitet och normalitet, även om relationen till föräldrarna inte självklart utgjorde ett stöd för dem.

Vi fann att planerna på att bilda egen familj var viktig hos ungdomarna. Utifrån begreppet resilience är förmågan att hitta en livspartner som kan utgöra ett stöd en viktig skyddande faktor. Det kan ha betydelse för möjligheten att distansera sig från sin ursprungliga familj vilket också kan ha en skyddande inverkan på de unga (Werner \& Smith 1992). Det var en svår balansgång ungdomarna hade att gå mellan att bygga upp nya stödjande strukturer och att återknyta till sina biologiska familjer. Dock fann vi att förmågan var stor hos ungdomarna att ta vara på det stöd som exempelvis en pojkeller flickväns familj kunde utgöra samtidigt som de upprätthöll kontakten med sin biologiska familj.

\section{Samhällets stöd}

Socialtjänsten, familjehemsvården och HVB-hemmen utgör de system som finns för att skapa skydd och stöd till unga som placerats inom dygnsvården. När de lämnar vården är det dock inte självklart att det stödet finns kvar. I våra resultat framgår det att kontakten med socialtjänsten i hög 
utsträckning upphör när ungdomarna avslutar sin placering. Om de sedan har fortsatt kontakt med fosterföräldrar och HVB-personal är det något som styrs av idealitet och välvilja från de vuxnas sida. I och med att kontakten med socialtjänsten upphör, finns inget formellt uppdrag från samhällets sida att fortsätta stödja de tidigare placerade ungdomarna.

Tidigare forskning visar att stöd till unga efter en avslutad placering kan få stor betydelse för hur de klarar sig (Andersson 2008). Utifrån ett resilience-perspektiv borde därför samhällets stöd på olika sätt finnas kvar under en längre tid under övergångsfasen från ung till vuxen. I och med att det formella stödet till de unga som lämnar vården upphör, blir också deras särskilda behov osynliggjorda. Konsekvensen av den svenska välfärdsmodellen kan för sårbara grupper av ungdomar bli att speciella behov av stöd under övergången från ung till vuxen inte artikuleras och synliggörs. När de lämnar vården övergår de till att kategoriseras som "tillhörande normalpopulationen"; det vill säga att de förutsätts ha samma förutsättningar och möjligheter att klara övergången från ung till vuxen som jämnåriga utan erfarenhet av att ha varit placerade i samhällets dygnsvård. Det innebär att risken är stor att ungdomar som lämnar dygnsvården därigenom inte får tillgång till adekvata resurser, och att de riskerar att marginaliseras.

\section{Ungdomar utan stöd}

De båda studiernas resultat visar att de som varit placerade i dygnsvård kan komma att ta steget ut i vuxenlivet under en komprimerad övergångsfas och med begränsat och villkorat stöd från familj, nätverk och samhälle. Formellt sett har denna grupp ungdomar samma rätt som ungdomar i allmänhet att ta del av samhällets stödinsatser. De kan söka studielån och om de inte vill studera och inte lyckas få arbete kan de söka försörjningsstöd. Emellertid menar vi att vår egen och den internationella forskningen på området (Höjer \& Sjöblom 2010; Stein 2002) visar att dygnsplacerade ungdomar befinner sig i en särskild situation som på många sätt skiljer sig från deras jämnåriga. Ungdomar som har växt upp $i$ sin familj och har kvar sitt ursprungliga nätverk befinner sig i en betydligt mer gynnsam situation då de skall ta steget ut i vuxenlivet.

Ett exempel som belyser denna skillnad är behovet av att "pröva sina vingar" under den här perioden i livet, att exempelvis börja en utbildning eller en anställning, pröva att flytta tillsammans med en partner och få lov att ångra sina val. För de ungdomar som inte har varit placerade i dygnsvård är det oftast möjligt att flytta tillbaka till föräldrarna om man behöver det. Det är också lättare att ta risken att använda sitt studielån till en utbildning även om man inte är helt säker på sitt val, vissheten om att det kan finnas en ekonomisk buffert i det privata nätverket tillåter ett sådant risktagande. Det som Walther (2006) benämner som jo-jo övergångar innefattar skapandet av en accepterad tidsrymd som präglas av möjligheten att pröva sig fram för de flesta ungdomar. För ungdomar som lämnar dygnsvården kan en sådan övergångsfas som kännetecknas av ett prövande 
och en möjlighet av att gå "fram-och-tillbaka" i förhållande till föräldrar eller andra signifikanta vuxna bli omöjlig. Risken är stor att det inte finns någon som kan fånga upp dem och finnas som ett stöd $i$ bakgrunden. Walther (2006) menar att ett av demokratins kännetecken är att det finns möjligheter för medborgare att göra individuella val. Här ser vi ett demokratiproblem - om dessa sårbara ungdomar inte kan göra individuella val på liknande villkor som deras jämnåriga, då är också demokratin för dem satt ur spel.

Ungdomar som lämnar dygnsvård är $\mathrm{i}$ en mening "samhällets barn". Staten har beslutat att skilja dessa ungdomar från sina biologiska föräldrar med uppsåtet att vilja dem väl och förbättra deras förutsättningar till ett bra liv. Därmed tar samhället på sig ett ansvar som borde vara likställt med ett föräldraansvar, vilket också skulle innebära att förbereda placerade ungdomar för ett självständigt vuxenliv. Det ansvar som samhället tar på sig i och med en placering i familjehem eller på HVB-hem bör därför utsträckas i tid, struktureras, tydliggöras och anpassas efter de förändrade förutsättningar som den förlängda ungdomstiden innebär.

\section{Sårbara och kompetenta på sammagång}

Rutter (1998) menar att utsatta ungdomar som har erfarenhet av svåra familjeförhållanden behöver känna att de har kontroll över sina liv och att det ökar deras förmåga att komma över svårigheter och få tillgång till en positiv utvecklingsbana i livet. Vi fann att detta på olika sätt kom till starkt uttryck i vårt empiriska material. Att ha boendet ordnat, att ha ett jobb och egen försörjning skapar en känsla av kontroll, självständighet och trygghet. Att dessutom ha en nära relation med en pojk- eller flickvän och i bästa fall kontakt både med sina biologiska föräldrar och/eller fosterhemsföräldrar ger ytterligare stabilitet. De unga vi har intervjuat har på många sätt visat sig kompetenta att forma sina vuxenliv mot ökad stabilitet både på ett yttre och inre plan, trots sin utsatthet.

Tidigare forskning baserad på registerstudier, har givit betydelsefull information om ungas liv efter att de har lämnat dygnsvården och visat att deras situation ofta blir problematisk (Vinnerljung et al. 2006; Social rapport 2010). Resultaten från den här studien ger en mer komplex och mångfacetterad bild av ungas liv efter vården. Individuella variationer, risk och skyddsfaktorer, skolerfarenheter, stöd från nätverk, familj och samhälle är alla viktiga faktorer för en gynnsam övergång från vård till ett självständigt liv. Vi har endast följt ett litet antal unga under en kort tid, men ungdomarnas egna utsagor skapar en förståelse för hur de själva upplevde övergången efter vården mot ett vuxenblivande, och hur de beskrev att de formade sina liv och lägger därmed till viktig kunskap om den här fasen $i$ livet för en grupp utsatta och sårbara ungdomar. 


\section{Referenser}

Andersson, G. (2008) Utsatt barndom - olika vuxenliv - ett longitudinellt forskningsprojekt om barn i samhällsvård. Stockholm: Stiftelsen Allmänna Barnhuset.

Andersson, G. (2005) När barnet står mellan familj och fosterfamilj. Socionomen nr 4.s.12-17.

Bakketeig, E. (2008) Forskningskunskap om ettervern. Rapport nr 17/08. NOVA.

Biehal, N., Clayden, J., Stein, M. \& Wade, J. (1995) Moving On: Young People and Leaving Care Schemes. London: HMSO.

Biehal, N. \& Wade, J. (1996) Looking Back, Looking Forward: Care Leavers, Families and Change. Children and Youth Services Review, vol.18, 4-5, s. 425-445.

Broad, B. (1999) Young People Leaving Care: Moving Towards "Joined Up" Solutions. Children and Society, vol 13, s. 81-93.

Courtney, M. \& Wong, I. Y. (1996) Comparing the timing of exits from substitute care. Children \& Youth Services Review, vol 18. 4/5,s. 307-334.

Esping-Andersen, G. (1990) The three worlds of welfare capitalism. Cambridge: Polity Press.

Esping-Andersen, G. (1999) Social Foundations of Postindustrial Economics. Oxford: University Press.

Espvall, M. \& Dellgran, P. (2006) ULF's sociala sida. Om socialt stöd och sociala nätverk i levnadsnivåundersökningarna. Socialvetenskaplig tidskrift, vol.1, s. 3-18.

Eydal, G-B. \& Satka, M. (2006) Social work and Nordic welfare policies for children - present challenges in the light of the past. European Journal of Social Work, vol 9, nr 3, pp. 305-322.

Franzén, E. \& Vinnerljung, B. (2006) Fosterchildren as young adults: many motherless, fatherless or orphans. A Swedish national cohort study. Child and Family Social Work, vol 3, pp. $254-263$.

Garnett, L. (1992) Leaving care and after, London: National Children's Bureau.

Havik, T. \& Backe-Hansen, E. (1998) Kunnskapsstatus för fosterhjemsarbeide. Bergen: Barnevernets Utviklingscenter.
Hellevik, T. (2005) På egne ben. Unges etableringsfase $i$ Norge. Oslo: NOVA (Norsk institutt for forskning om uppvekst, velferd og aldring), rapport 22/05.

Höjer, I. (2001) "Fosterfamiljens inre liv". Avhandling. Göteborgs universitet.

Höjer, I. \& Sjöblom, Y. (2010) Young People Leaving Care in Sweden. Child and Family Social Work, vol. 15, s. 118-127.

Jones, G. (1995) Leaving Home. Buckingham: Open University Press.

Little, M. Leitch, H. \& Bullock, R. ( 1995) The care careers of long-stay children: The contribution of a new theoretical approaches. Children and youth services review, vol, 17, pp. 665-679.

Lagerberg, D. \& Sundelin, C. (2000) Risk och prog nos $i$ socialt arbete med barn. Stockholm: Gothia.

Masten, A., Burth, K., Roisman, G., Obradovic, J., Long J. \& Tellgen A. (2004) Resources and resilience in transition to adulthood: Continuity and chances. Development and psychopahology, vol.16, p 107-1094.

Moen, P (1997) Women's roles and resilience: trajectories of advantage or turning points. In: Gotlieb I. \& Wheaton B. (red.) Stress and Adversity over the Life Course. Cambridge: Cambridge University Press.

Mørch, S. (1996) Individualisering och deindividualisering: perspektiv på unga och våld. I Isenberg B. \& F. Oddner (red.). Seendets pendel: fest skrift till Johan Asplund. Brutus Östlings bokförlag Symposium.

Nordström, C. \& Thunved, A. (2009) Nya socialtjänstlagarna. Stockholm: Nordstedts juridik.

Rutter, M., Giller, H. \& Hagell, A. (1998) Antisocial Behaviour by Young People. Cambridge: Cambridge University Press.

Rutter, M. (1999) Resilience concepts and findings: implications for family therapy. Journal of Family Therapy, vol. 21, pp 119-44.

Sallnäs, M. (2000) Barnavårdens institutioner: framväxt, ideologi och struktur. Institutionen för socialt arbete, Stockholms universitet. Avhandling.

Ingrid Höjer \& Yvonne Sjöblom: Att stå på egna ben - om övergången... 
Sjöblom, Y. (2002) På väg ut. När ungdomar rymmer och kastas ut hemifrån- ur socialtjänstens perspektiv. Institutionen för socialt arbete, Stockholms universitet. Avhandling.

Socialstyrelsen (2009) Barn och unga - insatser år 2008. Stockholm: Socialstyrelsen.

Socialstyreslen (2010) Social rapport 2010. Stockholm: Socialstyrelsen.

SOU (2001:55) Barn och ungdomars välfärd. Kommittén Välfärdsbokslutet.Stockholm 2001.

Stattin, H. \& Magnusson, D. (1996) Antisocial development: a holistic approach. Development and Psychopathology, vol. 8, 617-645.

Stein, M. (2002) Leaving Care. I McNeish, D., Newman, T. \& Roberts, H. (eds.) What Works for Children? Buckingham: Open University Press.

Stein, M. (2005) Resilience and young people leaving care. York: Joseph Rowntree Foundation.

Stein, M. (2006) Research Review: Young people leaving care. Child and family social work, vol. 11, pp 273-279.

Stein, M. (2008) Transitions from care to adulthood: messages from research. In M. Stein and E. Munro (eds.) Young People's Transitions from Care to Adulthood: International research and practice, London: Jessica Kingsley. pp. 289-306.

Stenström, N. (1998) Utslussning och eftervård vid de särskilda ungdomshemmen. Stockholm: SiS.

Ungdomsstyrelsen (2005) Fokus 05. En analys av ungas etablering och egen försörjning. Ung- domsstyrelsens skrifter 2005:10.

Vinnerljung, B. (1996) Fosterbarn som vuxna. Arkiv, Lund.

Vinnerljung, B., Sallnäs, M. \& Kyhle-Westermark, P. (2001) Sammanbrott vid tonårsplaceringar - om ungdomar i familjehem och på institution. Stockholm: CUS, Socialstyrelsen.

Vinnerljung, B., Hjern, A. \& Lindblad, F. (2006) Suicide attempts and severe psychiatric morbidity among former child welfare clients - a national cohort study. Journal of Child and Psychiatry, vol. 47 Issue 7, pp 723-733.

Vogel, J. (2002) European Welfare Regimes and the Transition to Adulthood: A Comparative and Longitudinal perspective. Social Indicators Research, vol 59, pp. 275-299.

Wade, J. (1999) Developing leaving care services: tapping the potential of foster carers. In Hill, M. (ed.) Signposts in fostering. Policy, practice and research issues, $46-62$. London: British Agencies for Adoption and Fostering.

Walther, A. (2006) Regimes of youth transitions: Choice, flexibility and security in young people's experiences across different European contexts. Young, vol.14, pp 119-139.

Werner, E. \& Smith, R. (2003) Att växa mot alla odds. Stockholm: Svenska föreningen för psykisk hälsa (sfph).

West, A. (1995) You're on your own. Young Peoples Research on Leaving Care. London: Save the Children. 


\section{Summary}

\section{Standing on your own two feet Young people's transition from care to adulthood}

The transition from care to an independent life can be a problematic phase for young people. What happens to young people when they leave a placement in outof-home care? This article draws on the results of a study in which 16 young care leavers between the ages of 18 and 22 were interviewed on two occasions, 1-2 years afterwards. Telephone interviews were also performed with the young care leavers' parents, social workers, foster carers and institutional staff. The aim of the study was to investigate how young care leavers perceive the transition from care to an independent life. The idea of the prolonged transition to adulthood, resilience as well as welfare discourse, and the implications for young care leavers have been used as analytical perspectives. The results show that young care leavers have a pronounced need for social, emotional, practical and financial support. Whilst such support is occasionally provided by foster carers and residential staff, it is seldom given by social services or biological parents. This group is at risk of facing severe problems in the transitional phase from care to independent life, a fact which is not yet acknowledged by the Swedish welfare system. 